\title{
Determinants Influencing Information Transparency in Vietnamese Commercial Banks
}

\author{
Minh Phuong NGUYEN ${ }^{1}$, Thi Hong Hai NGUYEN², Phuong Dung HOANG ${ }^{3}$, Manh Dung TRAN4, \\ Quang Trung PHAM ${ }^{5}$
}

Received: September 01, 2020 Revised: October 26, 2020 Accepted: November 16, 2020

\begin{abstract}
Information transparency ensures that market players all have the opportunity to access the same information to come up with their assessment of the banks' financial situation, performance and risks to reach effective investment decisions. This research is conducted to investigate the levels of impact of determinants on information transparency by examining the case studies of Vietnamese commercial banks. This study combines both qualitative and quantitative research methods, based on interviews of 32 specialists in banking, accounting and auditing fields, which were conducted to explore determinants influencing information transparency and to develop measurement scales. Then, a survey of 160 managers of commercial banks, audit firms, and accounting managers of firms who frequently had transactions with banks was carried out to investigate the statistical significance of these determinants. The results show that, out of seven determinants that have significant impacts on the banks' information transparency, commitment from banks' senior management regarding transparency in information disclosure has the highest impact, followed by state governance, auditing, information infrastructure, credit rating agencies, personnel and bank performance. Accordingly, we provide some recommendations for improving information transparency in the Vietnamese banking industry context as a case study and in emerging countries context in general.
\end{abstract}

Keywords: Information Transparency, Commercial Banks, Determinants, Vietnam

JEL Classification Code: O16, P33, P45

\section{Introduction}

In recent years, Vietnam's banking industry has developed at relatively fast pace thanks to economic reforms and integration as well as the restructuring

${ }^{1}$ First Author, Banking Academy, Vietnam.

Email: phuongnm@hvnh.edu.vn

²Banking Academy, Vietnam. Email: hainth@hvnh.edu.vn

${ }^{3}$ Research Scholar, Banking Academy, Vietnam.

Email: dunghp@hvnh.edu.vn

${ }^{4}$ Corresponding Author. Associate Professor, National Economics

University, Vietnam [Portal Address: 207 Giai Phong Road, Hai Ba

Trung District, Hanoi, 100000, Vietnam]

Email: manhdung@ktpt.edu.vn

${ }^{5}$ Professor, National Institute of Education Management, Vietnam.

Email: trung2012neu@gmail.com

(C) Copyright: The Author(s)

This is an Open Access article distributed under the terms of the Creative Commons Attribution Non-Commercial License (https://creativecommons.org/licenses/by-nc/4.0/) which permits unrestricted non-commercial use, distribution, and reproduction in any medium, provided the original work is properly cited. initiated by the State Bank of Vietnam. Moreover, since joining World Trade Organization in 2007, Vietnam has witnessed, not only an increasing number of domestic banks, but also the penetration of foreign banks. Besides banking services, bank customers always have alternatives offered by informal financial sources available. As a result, the Vietnamese banking industry has become increasingly competitive and gaining customer loyalty for sustainable, so growth is becoming more difficult for banks. Information transparency has been confirmed as an indicator of trustworthiness of both privately and publiclyowned organizations as well as a sign of organizational ethics in many previous studies such as Mabillard and Pasquier (2016), Ruijer (2013), Turilli and Floridi, (2009). In the banking industry where trust plays an important role in gaining customer loyalty and therefore, ensuring the sustainable growth of commercial banks in particular and the whole banking industry in general (Plasmeijer \& Raaij, 2017), the role of sustaining information transparency is paramount. 
As a transitional economy, formal institutions in Vietnam in general and those related to banking information transparency are still incomplete. Specifically, although fostering banking information transparency was emphasized as a crucial solution to ensure fairness and efficiency in access to credit and investment among individuals and organizations according to the Decision No.19-2017 issued by the Vietnam government, the regulation requirement related to banking information transparency demonstrated many gaps that create inefficiency and difficulties in enforcement. In fact, governmental regulation of information transparency is mentioned either directly or indirectly in many sources of law such as Accounting Law, Law of Statistics, Auditing Law, Law on Enterprises, Law on Securities, Degree No. 48/2014 issued by State Bank of Vietnam and Degree No. 155/2015 issued by Ministry of Finance. However, while the Accounting Law, the Law on Enterprises and Law on Securities do not regulate the sanctions against organizations that violate requirements of information transparency, the penalties for these violations regulated in the Law on Statistics and the Auditing Law are too small in comparison with benefits that the organization may obtain from frauds in financial information disclosure. Moreover, in either the Degree No. 48/2014 issued by State Bank of Vietnam or Degree No. 155/2015 issued by Vietnam Ministry of Finance, banks are required to public their financial reports on websites, head offices and branches, however, regulations about which information should be disclosed are not specified. As a result, banks may only disclose "good" indicators to the public. Due to these incomplete regulation requirements, Vietnam commercial banks' enforcement to ensure information transparency has been inefficient for years. Instead, a comprehensive understanding of determinants affecting information transparency in banking business due not only to banks' pressures, but also their willingness to do so, should be of more concern.

Despite the critical role of information transparency in the banking industry, there is hardly any research which both explores and statistically investigates its determinants in the Vietnamese context. Although there have been some studies on this topic conducted in other countries, most of this research was conducted in developed countries or countries with high financial inclusion and well-developed market institutions. Therefore, we suggest that there is a need to conduct research on information transparency in Vietnam where there is a low financial inclusion rate and under-developed market institutions. The special context of Vietnam may either change the nature and importance of information transparency's determinants, which have been found or added some new determinants that influence information transparency.
This research was conducted in two phases. Firstly, interviews of 32 specialists in banking, accounting and auditing were conducted to explore the determinants influencing information transparency in order to develop a conceptual model and measurement scales for each construct in the model. After that, a survey method was adopted to confirm and compare the significance of each factor through the utilization of OLS on SPSS. Findings from this research are then analyzed and discussed to provide helpful implications for bank management and policymakers in improving information transparency.

\section{Literature Review}

The literature reveals various concepts of information transparency. Regarding the public governance perspective, the Basel Committee (1998) defined financial information transparency of banks as the timely, reliable and comprehensive announcement to the public, so as to ensure that the users of such information can accurately assess the banks' financial situation and performance, business operations and related risks. Based on the views of enterprises, Bushman (2003) has drawn the concept of the financial market's information transparency as the availability of specific company information for outside investors and shareholders. From the perspective of users of information, Kulzik (2004) proposed seven dimensions to evaluate the transparency in provision of financial market's information including accuracy, consistency, appropriateness, comprehensiveness, clearness, timeliness, and convenience. From the perspective of auditors, Zarb (2006) defined information transparency in financial markets as the provision of useful and timely financial information, and the publishing of information must be reliable, comparable and consistent. It is also found that firms with higher levels of financial transparency are associated with significantly lower costs of equity capital. By increasing the level of corporate reporting, firms not only increase their stock market liquidity, but also decrease the investors' estimation risk, arising from uncertainty about future returns and payout distributions. Firms on the Kazakhstan market can reduce their cost of equity capital by increasing the level of their voluntary corporate disclosures (Baimukhamedova et al., 2017).

Basel (2001), that proposed three pillars of market discipline, pointed out five principles of information disclosure for banks, including clarity, comprehensiveness, meaningfulness to users, consistency, and comparability. Basel's requirements significantly increase the information that a bank must publish, allowing the market to have a more complete picture of the bank's overall risk position. In this research, transparency of information in banking industry refers to the process of reliable, timely, accurate, and 
convenient guidance in the provision of information about banks for specialized management agencies and investors, so as to ensure that market players all have the opportunity to access the same information in support of their assessment of banks' financial situation, performance and risks for effective investment decisions.

Much of previous research investigates the consequences, or benefits of information transparency to banks. Specifically, Flannery and Thakor (2006) affirmed that the more transparent the banks are, the more sympathy they receive from supervisory agencies. In addition, Tadesse (2006) asserted that banks need to enhance information transparency because this will reduce the likelihood of crisis. Bauman and Nier (2004) investigated the relationship between the level of volatility in banks' security prices in long term and the level of transparency in banks' annual reports and concluded that the more transparent banks' information is, the more benefits the investors' gain. Another research by Bauman and Nier (2006) indicated that the more transparent information a bank publishes, the more motivation is created for banks to manage risks. In general, the more transparent the bank's information is, the more profitability it will be. Iren et al. (2014) conducted a survey with large samples of banks in the US in the period 2001-2008 and concluded that larger banks often have greater levels of transparent information. Even in terms of the central banks, many countries' governments give their monetary authorities higher independence and transparency to achieve the price stability goal (Nurbayev, 2015).

In contrast, there is little research that investigated the determinants of banks' information transparency, especially in emerging countries. A study by Srairi and Douissa (2014) is one of the most notable one that investigates determinants influencing bank transparency in emerging markets. Specifically, they conducted a survey with a sample of 69 banks operating in seven emerging economies and initially suggested four main determinants that influence banks' information transparency, including bank's characteristics, governance variables, macroeconomic, and juridical indicators. Findings from regression analysis revealed that only corporate governance attributes, economic determinants and juridical determinants significantly affect banks' information transparency. Due to the distinct context of Vietnam banking industry in terms of underdeveloped market institutions and low financial inclusion, the set of determinants that have impacts on information transparency of banks in case of Vietnam may be different. The research by Srairi and Douissa (2014) has also not pointed out the key determinants that have the most effect on banks' information transparency. Therefore, there is still a need to have a separate research on determinants of banks' information transparency with a focus on Vietnam context.
In the context of Vietnam, although there have been many studies on information transparency, these studies put emphasis only on listed firms on the stock market (Tran et al., 2014; Hoang, 2011; Nguyen, 2012). For example, Nguyen and Nguyen (2020) investigate the effect of the factors on the disclosure of sustainable development information of 120 manufacturing companies listed on Vietnam stock market in 2019 to show that five variables have a statistically significant positive effect on disclosure of sustainable development information of manufacturing companies, including firm size, independence of board of directors, foreign ownership, return on equity, and financial leverage. Meanwhile, there is hardly any research that either uses qualitative research methods to explore the determinants of information transparency in Vietnam banking industry or tests such determinants with a statistical analysis.

In order to fill this knowledge gap, we firstly used quantitative research method with the interviews of 32 specialists in banking, auditing and accounting fields. The respondents' answers were then coded and combined with existing literature to be conceptualized into key determinants. Accordingly, seven determinants emerged that may have impacts on banks' information transparency, including state governance, auditing, availability of credit rating agency, senior management's commitment, business performance of commercial banks, quality of human resources as well as technology infrastructure.

The following section will further discuss the relationship between each of the above determinants and banks' information transparency, followed by hypothesis development.

\subsection{State Governance in Information Transparency}

State governance plays a critical role in ensuring information transparency in any country. The legal environment will create conditions for market participants to better understand their information disclosure obligations, what information needs to be disclosed as well as what information is deemed to be periodically or unexpectedly required by supervisory agencies, investors and the public.

A transparent information environment needs effective sanctions to strictly deal with violations. The effective legal environment will help strengthen information management by promoting compliance with information disclosure requirements among market players in which the state management agencies themselves need to showcase their information transparency in their supervision and handling of violations (Nguyen, 2012). In case of loose state management, it will cause insecurity for investors and sometime create abnormal fluctuations of the market (Truong \& Nguyen, 2017). Any delay or concealment of the 
information of listed firms will greatly affect the investors' decisions and beliefs on listed shares and commercial banks are no exception. On the other hand, the existence of government regulation can increase disclosure, especially the various voluntary disclosure initiatives are unlikely to succeed if there is no pressure from the government in the form of binding regulations. The company seeks to comply with government regulations to maintain its viability and to build a good reputation in the community (Faisal et al., 2020). In line with previous studies, we formulate the following hypothesis:

H1: The more rigorous state governance is, the higher the level of information transparency achieved.

\subsection{Auditing}

Commercial bank audits are conducted by independent audit firms or state audit agencies (i.e., also referred as external audits) and internal audits. External audit has diverse objectives including compliance audit (i.e., to assess the banks' compliance with processes, activities and legal regulations), auditing the financial statements (i.e., to check whether the financial statements are honest and credible), or operational audits (i.e., to assess the effectiveness and efficiency of a business process or outcome). Accordingly, external auditing has an important influence on information transparency of commercial banks. External audit results are reliable information for users to make appropriate management decisions. Commercial banks often publicize independent audit reports together with their financial statements as an inseparable part of annual reports or financial statements. Although the preparation and presentation of financial statements are the responsibilities of the management of the audited banks, the auditing results revealed by the outsourced auditing agencies may affect the amount of information disclosed (Nguyen, 2015).

On the other hand, auditing can provide management consulting services to help commercial banks improve their business operations. This is one of the functions that the auditing agencies, especially those that conduct internal audits, bring to the bank. Internal audit is an internal part of the commercial bank's operation, the third and final protection layer in the three levels of corporate value protection, which is responsible for independent and objective confirmation and consultation set up to create value added, improve the performance of an organization. Internal audit helps organizations achieve their goals by creating a systematic and disciplined approach to assess and enhance the effectiveness of corporate governance processes as well as the processes of risk control and management (IIA, 2009). The strong internal audit system helps ensure transparency of information disclosed by banks. However, the results of internal audit are not publicized outside the enterprise. Instead, internal audit reports are presented to the senior managers who will coordinate with the relevant parties including external auditors to take remedial measures (IIA, 2012). The following hypothesis is, therefore, proposed:

H2: Auditing is positively related to the level of information transparency.

\subsection{Credit Rating Agencies}

In the context of the risk of asymmetric information and opposing choices, the ratings suggested by reputable credit rating agencies will be a good basis for investors to make decisions. The credit rating agency is usually a prestigious international or national organization with expertise to collect, process and publish data on the "health" of businesses, including banks. These agencies often evaluate businesses with a large, comprehensive and complete set of criteria in many respects. Therefore, if commercial banks are rated by credit ratings agencies as trustworthy, it is likely that these ranked commercial banks have advantages and be professional in providing sufficient and transparent information to the public.

Boot (2010) asserted that investors' interest in credit rating has increased over the past 20 years. Since financial transactions grew in both quantity and complexity while accessing to comprehensive information is very expensive, investors utilizes credit rating firms for accurate assessments. However, compared to other businesses, banks often pose more challenges for credit rating firms. Banks often face a variety of risks, especially risks due to opposing choices and legal interventions. Therefore, credit ratings on banks can only achieve a lower bound or encounter bad situations in quality assessment in comparison to other businesses (Morgan, 2002). The following hypothesis is, therefore, proposed:

H3: Pressures from credit rating agencies have positive impacts on banks' information transparency

\subsection{Transparency Commitment by Senior Managers}

If commercial banks do not want to disclose transparent information or delay in doing so, they may distort and manipulate data in the financial statements. Information transparency cannot rely solely on the role of regulatory agencies, but also depends on other determinants, especially 
the initiatives of business leaders. Business ethics or social responsibility of management boards of commercial banks, including listed banks with poor performance, is a fundamental cause of constraints in information disclosure and transparency (Nguyen, 2014). If senior managers are fully aware that responsibilities and obligations in providing transparent information plays a critical role in helping their businesses operate sustainably, they will transmit this message through the entire business operations. On the contrary, if they are unaware or not fully aware of the impact that information transparency has on the longterm development of the bank, then neither department nor employees within the bank will take responsibility for information. If commercial banks do not want transparent information, they may have distortions and manipulate data on the financial statements. Information transparency cannot rely on the sole role of regulatory agencies, but also depends on determinants, especially the initiative of business leadership (Dao, 2018). Khanifah et al. (2020) also provide the evidence that Islamic bank with higher level of corporate governance disclosure reported high operating performance measure by ROA.

Ethics in business or social responsibility of management boards of commercial banks, including poorly listed banks, is a fundamental cause of information disclosure and transparency constraints (Nguyen, 2014). If senior management is acutely aware of the responsibility, obligation to provide and transparent information is an integral part to help businesses operate sustainably, then they will transmit this message in the entire application. On the contrary, if the highest-level leaders in the unit are unaware or not fully aware of the impact of transparent information on the long-term development of the bank, then neither an individual nor a department can take responsibility for information transparency simply because they are neither required nor encouraged. This study, therefore, hypothesizes that:

H4: Senior managers' transparency commitment is positively correlated with the level of information transparency of commercial banks

\subsection{Banks' Performance}

The better the business results, the higher the desire of the banks to communicate such results to the public as a way to satisfy investors, and create conditions to attract investment in the future. When business performances are poor or deteriorating, business leaders tend to hide them due to their concerns about the banks' ability to mobilize capital, business prestige and the likelihood of investors' withdrawal. Wallace and Naser (1995) and Raffournier (1995) have pointed that business results, especially profit, represent an important factor, which positively correlated with the level information disclosure. In addition, highprofit firms often receive more attention from state management agencies. Therefore, they usually try harder to disclose transparent information in their reports to explain their financial achievements (Nguyen, 2015). This study, therefore, hypothesizes that:

H5: Banks' performance positively affects information transparency

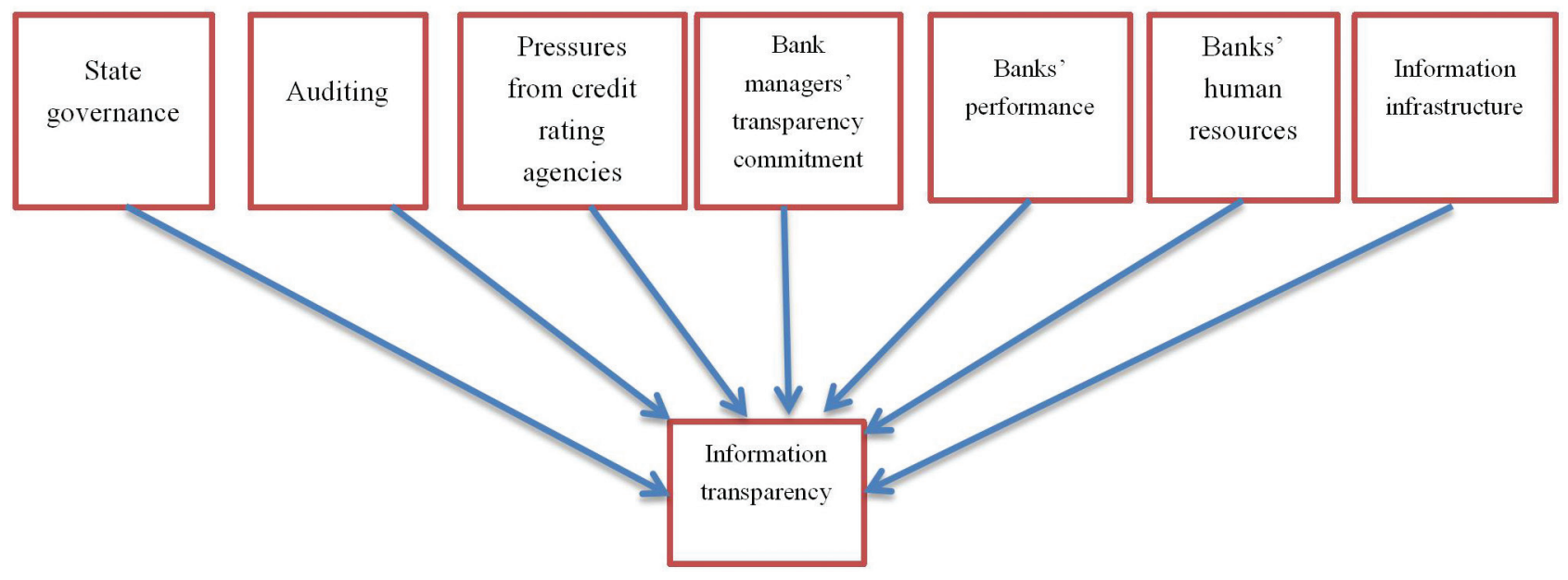

Figure 1: Proposed conceptual framework 


\subsection{Human Resource}

In order to manage and operate the market in the context of increasing international integration, the human factor must be put more emphasis (Dul et al, 2012). They revealed that the knowledge of individuals and organizations regarding the market and, thereby, the importance and benefits of information transparency will help disclosure of transparent information becomes much more effective and desirable. So, we formulate the following hypothesis:

H6: Banks' human resources positively influence information transparency

\subsection{Information Infrastructure}

Modern technical facilities willallow quick and complete information disclosure in which advanced technology will help ensure the safety and security of information as well as reduce the time spent for information processing process (Nguyen, 2015). In addition, the finding from interviews added that IT infrastructure of the governmental bodies and local authorities, especially those are directly related to publicity and transparency of commercial banks' information, also affect banks' information transparency. Specifically, if the information technology platform in these organizations is not improved, still based on manual operations, and not synchronized with each other and with commercial banks, the process of information disclosure of commercial banks will be more difficult. This study, therefore, we hypothesize that:

H7: Information infrastructure has a positive impact on information transparency

\section{Research Methodology}

The research combined both qualitative and quantitative research methods in which the qualitative method was employed to explore the determinants influencing information transparency and develop the measurement scales followed by a survey, which further confirmed the statistical significance of each factor. Accordingly, the research was conducted in two phases:

\section{Phase 1:}

Individual interviews were conducted with 32 specialists in banking, auditing and accounting sectors. The participants are selected to ensure the diversity of expertise and their involvement with banking information's transparency. We kept recruiting participants and conducting interviews until the exploratory purposes of our qualitative research were achieved. Experts were asked to give comments about the transparency of banks' information disclosure as well as give their own opinions about what determinants contribute to such good or poor information transparency. Each interview lasted 30 to 45 minutes. Since information transparency is a sensitive topic, all the information provided by the respondents was noted in handwriting and promised to be kept secret, so that the participants felt free to give insightful information. NVivo10 was employed as data analysis tool, which enabled exploration and conceptualization of key determinants that may have impacts on information transparency.

\section{Phase 2:}

A survey method was adopted to test the significance of the proposed conceptual framework. Accordingly, an online questionnaire was designed and distributed to senior management of commercial banks located in Hanoi, the capital of Vietnam (i.e., chairman of the board of directors, chief accountant, chief or deputy head of departments, experts and management at the head office or large branches in Hanoi), managers of inspection agencies, state auditors or independent auditors who are knowledgeable about the banking industry as well as accountants and chief accountants of firms that have deposits and loans at commercial banks. These parties were selected as the sample of this research since all are involved with banks' information either as the information publishers (banks), the auditors (both independent audit firms, State Auditing Offices of Vietnam, Inspection and Supervision Office of State Bank of Vietnam) and the users of information (organizations which are currently bank customers). Data collection was conducted from October 2017 to January 2018. Among initial 180 sampling units, which were selected by convenience sampling method, only 170 responses were received. However, only 160 responses were usable due to missing data in which majority of respondents are banks' senior management $(86.9 \%)$. The sample size of 160 was acceptable for regression and factor analysis as suggested by previous research (Comrey, 1973; Hair et al., 2006; Tatham $\&$ Black, 1998). The detailed sample structure is presented in Table 1.

Measurement scales for the development of questionnaire were adapted from previous studies, except the measurement property for information transparency. Since the measurement scale for subjective evaluation or perception of information transparency is non-existent, we develop a measurement scale using findings from the interviews. Appendix 1 shows detailed measurement items used in this study. A 5-point Likert scale was employed to score each latent variable, with $1=$ Strongly disagree; $2=$ Disagree, $3=$ Neither agree or disagree, 4= Agree, 5= Strongly agree.

Data collected from the survey was first subjected to reliability test and exploratory factor analysis (EFA) so as to evaluate the reliability and validity of the measurement properties before the regression analysis for testing the proposed conceptual model. 
Table 1: Sampling size

\begin{tabular}{|c|c|c|}
\hline \multicolumn{2}{|c|}{ Sampling description } & \multirow{2}{*}{$\begin{array}{c}\begin{array}{c}\text { No. of sampling } \\
\text { units }\end{array} \\
14\end{array}$} \\
\hline \multirow[t]{17}{*}{ Banks } & Vietcombank & \\
\hline & BIDV & 9 \\
\hline & Vietinbank & 8 \\
\hline & Agribank & 29 \\
\hline & MB & 5 \\
\hline & HDBank & 27 \\
\hline & Techcombank & 5 \\
\hline & SHB & 2 \\
\hline & PVcombank & 13 \\
\hline & SHB & 3 \\
\hline & VIB & 3 \\
\hline & Hongleong Bank & 2 \\
\hline & $\mathrm{ACB}$ & 2 \\
\hline & Bac A Bank & 3 \\
\hline & An Binh Bank & 6 \\
\hline & PG Bank & 6 \\
\hline & Vietbank & 2 \\
\hline \multirow{2}{*}{$\begin{array}{l}\text { Independent } \\
\text { audit firms }\end{array}$} & Ernst \& Young & 2 \\
\hline & Deloitte & 3 \\
\hline \multicolumn{2}{|c|}{ State Auditing Offices of Vietnam } & 2 \\
\hline \multicolumn{2}{|c|}{$\begin{array}{l}\text { Inspection and supervision office } \\
\text { (State Bank of Vietnam) }\end{array}$} & 1 \\
\hline \multicolumn{2}{|c|}{$\begin{array}{l}\text { Organizations which use banks' } \\
\text { financial information }\end{array}$} & 13 \\
\hline
\end{tabular}

Table 2: Cronbach's Alpha coefficients

\begin{tabular}{|l|c|c|}
\hline Variables & $\begin{array}{c}\text { No. measurement } \\
\text { items }\end{array}$ & Cronbach's Alpha \\
\hline ST & 4 & 0.839 \\
\hline ADT & 4 & 0.859 \\
\hline CRA & 4 & 0.892 \\
\hline CMT & 5 & 0.896 \\
\hline BP & 2 & 0.723 \\
\hline HR & 3 & 0.713 \\
\hline IFS & 3 & 0.801 \\
\hline TRA & 3 & 0.811 \\
\hline
\end{tabular}

\section{Results and Discussion}

\subsection{Testing the Reliability of Variables}

In order to test the reliability or the internal consistency of the measurement items for each construct, Cronbach's Alpha was calculated with SPSS software. Accordingly, ST2 and CMT1 were deleted to ensure the acceptable reliability for measurement scales of state governance and bank management's commitments. Table 2 shows the Cronbach's Alpha coefficients for all eight constructs after ST2 and CMT1 were removed. These reliability indicators were acceptable (all Cronbach's Alpha values are higher than 0.7). Therefore, the reliability of these constructs was satisfactory.

In order to test the validity of the measurement scales, the remaining 25 measurement items, which measure seven independent variables, were subjected to EFA on SPSS with principal factor as extraction method followed by a varimax rotation. The EFA results showed eight determinants emerged subjected to how these constructs were initially measured. Results shown in Table 3 reveal that KMO indicator is greater than the threshold of 0,5 as suggested by Garson (2003), while Bartlett's test result has p value smaller than 0.05. Accordingly, conditions for EFA is satisfied. Furthermore, EFA results as presented in Table 5 indicate that all factor loadings are greater than the cut-off value of 0.5 . Based on guidance proposed by Anderson and Gerbing (1988), (p-value) sig $=0.000<0.05$ shows that the validity of the measurement for the seven constructs was confirmed.

According to the above results, we decided to retain the construct with its measurement items as shown in Table 4 to conduct the hypothesis testing. Specifically, the following regression model was tested using SPSS:

$$
\begin{aligned}
\mathrm{ITRi} & =\beta 0+\beta 1 \mathrm{STi}+\beta 2 \mathrm{ADTi}+\beta 3 \mathrm{CRAi}+\beta 4 \mathrm{CMTi} \\
& +\beta 5 \mathrm{BPi}+\beta 6 \mathrm{HRi}+\beta 7 \mathrm{IFSi}+\varepsilon
\end{aligned}
$$

Regression results in Table 5 shows the variance inflation factor (VIF) indicator for each dependent variable, which assesses how much the variance of an estimated regression coefficient increases if predictors are correlated is smaller than the recommended cut-off value of 5. Therefore, multicollinearity among independent variables is minor and does not significantly affect the regression results.

Table 3: KMO and Bartlett's test

\begin{tabular}{|l|c|}
\hline KMO and Bartlett's test \\
\hline KMO & 0.810 \\
\hline Bartlett's test & 2102.749 \\
\hline df & 300 \\
\hline Sig. & 0.000 \\
\hline
\end{tabular}


Table 4: EFA results

\begin{tabular}{|c|c|c|c|c|c|c|c|}
\hline \multirow{2}{*}{ Items } & \multicolumn{7}{|c|}{ Factor loadings } \\
\hline & 1 & 2 & 3 & 4 & 5 & 6 & 7 \\
\hline CMT4 & 0.883 & & & & & & \\
\hline CMT5 & 0.856 & & & & & & \\
\hline СMT6 & 0.797 & & & & & & \\
\hline СMT2 & 0.751 & & & & & & \\
\hline CMT3 & 0.726 & & & & & & \\
\hline CRA4 & & 0.853 & & & & & \\
\hline CRA3 & & 0.838 & & & & & \\
\hline CRA1 & & 0.836 & & & & & \\
\hline CRA2 & & 0.792 & & & & & \\
\hline ADT2 & & & 0.859 & & & & \\
\hline ADT3 & & & 0.823 & & & & \\
\hline ADT4 & & & 0.784 & & & & \\
\hline ADT1 & & & 0.772 & & & & \\
\hline ST1 & & & & 0.869 & & & \\
\hline ST5 & & & & 0.839 & & & \\
\hline ST4 & & & & 0.772 & & & \\
\hline ST3 & & & & 0.725 & & & \\
\hline IFS2 & & & & & 0.784 & & \\
\hline IFS1 & & & & & 0.776 & & \\
\hline IFS3 & & & & & 0.744 & & \\
\hline HR2 & & & & & & 0.875 & \\
\hline HR3 & & & & & & 0.706 & \\
\hline HR1 & & & & & & 0.703 & \\
\hline BP2 & & & & & & & 0.850 \\
\hline BP1 & & & & & & & 0.814 \\
\hline
\end{tabular}

Table 5: Regression analysis results

\begin{tabular}{|l|c|c|c|c|c|}
\hline \multirow{2}{*}{ Variables } & $\begin{array}{c}\text { Standardized } \\
\text { coefficients }\end{array}$ & \multirow{2}{*}{ t-value } & \multirow{2}{*}{$\begin{array}{c}\text { Sig. } \\
\text { (p-value })\end{array}$} & VIF & $\begin{array}{c}\text { Hypothesis } \\
\text { testing }\end{array}$ \\
\cline { 2 - 3 } & $\boldsymbol{\beta}$ & -2.905 & 0.004 & & \\
\hline (Constant) & & 4.731 & $<0.001$ & 1.186 & Accept H1 \\
\hline ST & 0.225 & 4.782 & $<0.001$ & 1.251 & Accept H2 \\
\hline ADT & 0.233 & 3.205 & $<0.001$ & 1.328 & Accept H3 \\
\hline CMT & 0.161 & 5.019 & $<0.001$ & 1.328 & Accept H4 \\
\hline BP & 0.252 & 2.428 & 0.016 & 1.249 & Accept H5 \\
\hline HR & 0.118 & 3.276 & 0.001 & 1.244 & Accept H6 \\
\hline IFS & 0.159 & 3.912 & $<0.001$ & 1.589 & Accept H7 \\
\hline
\end{tabular}


In addition, regression results in Table 5 also reveal that all of the seven determinants have statistically significant positive impacts on banks' information transparency with confidence interval of $95 \%$. Moreover, the model of these seven determinants collectively explain for $69.8 \%$ variance of banks' information infrastructure (i.e., Adjusted R2=0.698).

\subsection{Discussion}

The primary aim of this study is to identify determinants that affect transparency of information disclosed by banks, which plays an important role in the long-term sustainable development of banking industry, specifically in the context of Vietnam. Although there has been some research investigating determinants influencing banks' information transparency in other countries, there is still a need to conduct research focusing on Vietnam, which is characterized by underdeveloped market institutions and relatively low financial inclusion.

Since, there is insufficient comprehensive research in Vietnam that investigates and confirms determinants influencing banks' information infrastructure, this research firstly employed a qualitative method with interviews, so as to explore the determinants as well as develop hypotheses and measurement scales for each construct. Accordingly, seven determinants emerged as potential determinants of banks' information transparency including state governance, auditing, availability of credit rating agencies, senior management's commitment, business performance of commercial banks, quality of personnel and technology infrastructure.

A survey was therefore conducted to test the conceptual model incorporating these seven determinants as independent variables which have effects on information transparency as the dependent variable. Regression analysis results show that all these predictors significantly and positively affect banks' information infrastructure. Commitments from banks' senior management regarding transparency in information disclosure have the highest impact on information transparency with coefficient of 0.252 , followed by state governance, auditing, information infrastructure, credit rating agencies, personnel and bank performance correspondingly

Based on the findings, this study draws some helpful implications for bank management and policy makers. Firstly, similar to findings conducted by Srairi and Douissa (2014), this study also suggests that state governance plays an important role in enforcing information transparency among banks. Besides, auditing also has a positive effect on the integrity of banks in providing information to the public. However, this study reveals that the commitments from banks' senior management regarding transparency in information disclosure are even more important. In other words, state governance and auditing which forces banks to be transparent in information disclosure (i.e., because they feel that they "need" to do so) has less effects than the bank management's commitment (i.e., they "want" to do so) to ensuring information transparency. This may be due to the special context of Vietnam where laws and regulations on information disclosure are neither developed nor strict enough to enforce information transparency. Therefore, the best way to promote information transparency is by making banks' managements fully aware of the critical importance of disclosing transparent information and take initiatives to make commitments to doing so. Accordingly, the commitment and knowledge of banks' management about information transparency can be enhanced not only through powerful sanctions, but also appropriate mechanisms rewarding good behaviors, and training with seminars.

Along with bank senior management's commitment, whether information is provided transparently in actual practice also relies largely on the personnel directly involved with preparing and disclosing information. Therefore, ensuring sufficient quantity and quality of the workforces who deal directly with bank information while having effective sanctions and rewarding mechanisms for either enforcing or encouraging their integrity is critically important, especially for banks which take initiatives in ensuring information transparency.

Besides, the relatively strong relationship between information infrastructure and banks' information transparency implies that advanced information technology, especially under the evolution of Industry 4.0, will help gradually enhance transparency in information disclosure. Accelerating the application of high-tech core banking systems of all commercial banks that support comprehensive and consistent data input, storage and retrieval is an effective way to reduce unnecessary delays and improve transparency of bank reports while facilitating auditing activities.

Moreover, being favorably ranked by credit rating agencies will be the desire and motive of banks to do "good things". Accordingly, although government should encourage the development of credit rating agencies, the integrity and quality of service of these firms should be strictly controlled and regulated. Moreover, in order to create trust among the public towards these agencies, government should issue some forms of certificate for credit rating agencies which satisfy some specific criteria to be trustworthy. Finally, bank performance has significant positive impact on information transparency since banks are obviously willing to show their good performance, fostering the efficiency and growth of the whole banking industry is also another way to ensure information transparency. 


\section{Conclusion}

This study examines the determinants influencing information transparency of Vietnamese commercial banks in the context of Vietnam banking industry upon the employment of both qualitative and quantitative methods. The findings indicate that there are seven determinants affecting banks' information transparency including state governance, auditing, availability of credit rating agencies, senior management's commitment, business performance of commercial banks, quality of personnel and technology infrastructure. Among these determinants, commitments or the intention of banks' senior management have the highest impact on information transparency.

The study contributes to the literature by considering and analyzing the determinants which may influence information transparency that suits the context of Vietnam banking industry. The most notable finding is the impact of the commitment from the top managers on information transparency. Specifically, top managers are those who have the highest authority regarding how information is disclosed, and if they do not like to disclose information, they can have many ways to hide it. This study, therefore, provides important implications for the government authorities to enhance and develop banking industry.

This study has some limitations. Firstly, the study should have a bigger sample size for more reliable results. Secondly, the OLS regression results should be strengthened if the other tests such as bptest, bg test and reset test can be implemented.

\section{References}

Anderson, J. \& Gerbing, D. (1988). Structural equation modeling in practice: A review and recommended two-step approach. Psychological Bulletin, 103(3), 411-423.

Baimukhamedova, A., Baimukhamedova, G., \& Luchaninova, A. (2017). Financial Disclosure and the Cost of Equity Capital: The Empirical Test of the Largest Listed Companies of Kazakhstan. Journal of Asian Finance, Economics and Business, 4(3), 5-17. http://dx.doi.org/10.13106/jafeb.2017.vol4.no3.5

Basel Committee on Banking Supervision. (1998). Enhancing bank transparency, 4-6. Available at http://216.55.97.163/ wp-content/themes/bcb/bdf/int_regulations/BASEL/Basel_ Enhancing_Bank_transparancy.pdf.

Basel Committee on Banking Supervision. (2001). Consultative Document Pillar 3 (Market Discipline), 2-5. Available at https://www.bis.org/publ/bcbsca10.pdf

Baumann, U. \& Nier, E. (2004). Disclosure, Volatility, And Transparency: An Empirical Investigation Into The Value Of Bank Disclosure. FRBNY Economic Policy Review, 10(2), 31-45. Available at: https://core.ac.uk/download/ pdf/6792738.pdf.
BerglöF, E \& Pajuste, A. (2005). What do Firms Disclose and Why? Enforcing Corporate Governance and Transparency in Central and Eastern Europe. Oxford Review of Economic Policy, 21(2), 178-197.

Boot, A.W.A. (2010). The accelerating integration of banks and markets and its implications for regulation. The Oxford Handbook of Banking. Oxford, UK: Oxford University Press.

Bushman, R. \& Smith, A. (2003). Transparency, Financial Accounting Information, and Corporate Governance. Economic Policy Review, 9(1), 65-87.

Dao, H. (2018). Manipulating financial statements in listed companies and solutions. Finance Review, 4, 57-59.

Dul et al. (2012). A Strategy for Human Factors/Ergonomics: Developing the Discipline and Profession. Ergonomics, 55(4), 377-395.

Faisal, F., Situmorang, L.S., Achmad, T., \& Prastiwi, A. (2020). The Role of Government Regulations in Enhancing Corporate Social Responsibility Disclosure and Firm Value. Journal of Asian Finance, Economics and Business, 7(8), 509-518. https:// doi.org/10.13106/jafeb.2020.vol7.no8.509

Flannery, M. \& Thakor, A. (2006). Accounting, Transparency and Bank Stability. Journal of Financial Intermediation, 15(3), 281-284.

Fu, Y., Carson, E. \& Simnett, R. (2015). Transparency report disclosure by Australian audit firms and opportunities for research. Managerial Auditing Journal, 30(8/9), 870-910.

Hirtle, B. (2007). Public Disclosure, Risk and Performance at Bank Holding Companies. Federal Reserve Bank of New York Staff Reports, 293-302.

Hoang, T. (2011). Information disclosure issues of listed companies. Banking Review, 10(5), 15-25.

IIA (2012). Leading Practice, Transparency of The Internal Audit In Pubic Sector. The Institute of Internal Auditors. Maitland Avenue, USA.

Iren, P., Reichert, A.K., \& Gramlich, D. (2014). Does bank transparency matter? Banks and bank system, 9(1), 75-93.

Khanifah, K., Hardiningsih, P., Darmaryantiko, A., Iryantik, I., \& Udin, U. (2020). The Effect of Corporate Governance Disclosure on Banking Performance: Empirical Evidence from Iran, Saudi Arabia and Malaysia. Journal of Asian Finance, Economics and Business, 7(3), 41-51. https://doi.org/10.13106/ jafeb.2020.vol7.no3.41.

Kulzick, S. (2004). Sarbanes-Oxley: Effects on Financial Transparency. Advanced Management Journal, 69(1), 43-49.

Mabillard, V. \& Pasquier, M. (2016). Transparency and Trust in Government (2007-2014): A Comparative Study. NISPAcee Journal of Public Administration and Policy, 9(2), 69-92.

Morgan, D. (2002). Rating Banks: Risk and Uncertainty in an Opaque Industry. American Economic Review, 92(4), 874-888.

Nguyen, A. (2012). Information Transparency in Vietnamese Stock Market to Meet Requirements of International Economic Integration. PhD Thesis, Banking Academy of Vietnam. 
Nguyen, H. (2014). Quality of information disclosure of listed companies in Vietnam's stock market, current situation and solutions. VNU Journal of Science, 30(3), 37-45.

Nguyen, A., \& Nguyen, L. (2020). Determinants of Sustainability Disclosure: Empirical Evidence from Vietnam. Journal of Asian Finance, Economics and Business, 7(6), 73-84. doi:10.13106/ jafeb.2020.vol7.no6.073

Nguyen, H. (2015). Factors affecting the level of voluntary information disclosure of listed companies on HOSE. Journal of Economic Development, 26(11), 99-115.

Nurbayev, D. (2015). Independence and Transparency of the Central Bank of Kazakhstan. Journal of Asian Finance, Economics and Business, 2(4), 31-38. https://doi.org/10.13106/jafeb.2015. vol2.no4.31.

Plasmeijer, P., \& Raaij, F. (2017). Banking system trust, bank trust, and bank loyalty. International Journal of Bank Marketing, 35(1), 97-111.

Ruijer, H. J. M. (2013). Proactive Transparency and Government Communication in the USA and the Netherlands. PhD Thesis, Virginia Commonwealth University.

Srairi, S., \& Douissa, I. (2014). Factors Influencing Bank Transparency: Case of Emerging Markets. British Journal of Economics, Management \& Trade, 4(4), 523-540.
Tadesse, S. (2006). The economic value of regulated disclosure: Evidence from the banking sector. Journal of Accounting and Public Policy, 25(1), 32-70.

Tian, Y. and Chen, J. (2009). Concept of Voluntary Information Disclosure and A Review of Relevant Studies. International Journal of Economics and Finance, 1(2), 55-59.

Tran et al. (2014). Building a research model on factors affecting the quality of information disclosure of listed companies. $V N U$ Journal of Science, 30(3), 26-36.

Truong, L. \& Nguyen, A. (2016). Developing transparent indexes and disclose information for listed companies in the stock market of Vietnam. Banking Review, 22, 30-35.

Turilli, M. \& Floridi, L. (2009). The ethics of information transparency. Ethics and Information Technology, 11(2), 105-112.

Wallace, O \& Naser, K. (1995). Firm-specific determinants of the comprehensiveness of mandatory disclosure in the corporate annual reports of firms listed on the stock exchange of Hong Kong. Journal of Accounting and Public Policy, 14(4), 311-368.

Zarb, B. (2006). The quest for transparency in financial reporting. The CPA Journal, 76(9), 1-30. 
Appendix 1: Measurement scales

\begin{tabular}{|c|c|c|c|}
\hline Variables & Coding & Measurement items (Attributes) & Sources \\
\hline \multirow{5}{*}{$\begin{array}{l}\text { State governance } \\
\text { (ST) }\end{array}$} & ST1 & $\begin{array}{l}\text { Legal documents fully regulate information channels and } \\
\text { transparency of information }\end{array}$ & \multirow{5}{*}{$\begin{array}{l}\text { Truong \& Nguyen } \\
(2016), \text { Nguyen } \\
(2012)\end{array}$} \\
\hline & ST2 & $\begin{array}{l}\text { Regulations on sanctioning information disclosure violations are } \\
\text { sufficiently strict }\end{array}$ & \\
\hline & ST3 & $\begin{array}{l}\text { Regulations on sanctioning information disclosure violations are } \\
\text { comprehensive }\end{array}$ & \\
\hline & ST4 & $\begin{array}{l}\text { Regulations on sanctioning information disclosure are effectively } \\
\text { communicated }\end{array}$ & \\
\hline & ST5 & Regulations on sanctioning information disclosure do not overlap & \\
\hline \multirow{4}{*}{$\begin{array}{l}\text { Auditing } \\
\text { (ADT) }\end{array}$} & ADT1 & Auditing results are always publicized on the mass media & \multirow{4}{*}{$\begin{array}{c}\text { Nguyen (2015), IIA } \\
\text { (2012), Fu et al. } \\
\text { (2015) }\end{array}$} \\
\hline & ADT2 & Auditors always work positively and objectively & \\
\hline & ADT3 & $\begin{array}{l}\text { Commercial banks cooperate well in providing information for } \\
\text { independent auditors }\end{array}$ & \\
\hline & ADT4 & Auditing results reflect the bank's business performance properly & \\
\hline \multirow{4}{*}{$\begin{array}{l}\text { Credit ranking } \\
\text { agencies } \\
\text { (CRA) }\end{array}$} & CRA1 & $\begin{array}{l}\text { In order to get a good credit rating, commercial banks always } \\
\text { need good business results }\end{array}$ & \multirow{4}{*}{$\begin{array}{l}\text { Boot (2010), Morgan } \\
\text { (2002) }\end{array}$} \\
\hline & CRA2 & $\begin{array}{l}\text { Credit rating agency will transparently consider both good and } \\
\text { bad information of commercial banks }\end{array}$ & \\
\hline & CRA3 & $\begin{array}{l}\text { The working method of the credit rating agency is scientific, } \\
\text { honest and objective }\end{array}$ & \\
\hline & CRA4 & $\begin{array}{l}\text { Commercial banks always want to be ranked by credit rating } \\
\text { agencies }\end{array}$ & \\
\hline \multirow{6}{*}{$\begin{array}{l}\text { Bank manager's } \\
\text { transparency } \\
\text { commitments } \\
\text { (CMT) }\end{array}$} & CMT1 & $\begin{array}{l}\text { Commercial bank managers always instruct employees to comply } \\
\text { with all laws on information disclosure }\end{array}$ & \multirow{6}{*}{$\begin{array}{c}\text { BerglöF \& Pajuste } \\
(2005), \text { Nguyen } \\
(2014)\end{array}$} \\
\hline & CMT2 & $\begin{array}{l}\text { Senior leaders always create conditions for commercial banks to } \\
\text { strictly abide by all regulations on information disclosure. }\end{array}$ & \\
\hline & СMT3 & $\begin{array}{l}\text { There is a specific assignment for each department regarding } \\
\text { information disclosure }\end{array}$ & \\
\hline & CMT4 & $\begin{array}{l}\text { There are strict penalties for those who do not fulfill the task of } \\
\text { disclosing information }\end{array}$ & \\
\hline & CMT5 & $\begin{array}{l}\text { Bank managers always commit to transparently disclose } \\
\text { information even if it is unfavorable for banks. }\end{array}$ & \\
\hline & CMT5 & $\begin{array}{l}\text { Bank managers always respect honesty in disclosing information } \\
\text { by never making up financial statements }\end{array}$ & \\
\hline \multirow[b]{2}{*}{$\begin{array}{l}\text { Bank performance } \\
\text { (BP) }\end{array}$} & BP1 & $\begin{array}{l}\text { When banks have satisfactory business results, these information } \\
\text { are widely published on mass media. }\end{array}$ & \multirow{2}{*}{$\begin{array}{c}\text { Wallace \& Naser } \\
\text { (1995), Nguyen } \\
\text { (2015). }\end{array}$} \\
\hline & BP2 & $\begin{array}{l}\text { When banks have poor business results, they tend to delay } \\
\text { information disclosure or publish less information }\end{array}$ & \\
\hline
\end{tabular}


Appendix 1: Continued

\begin{tabular}{|c|c|c|c|}
\hline \multirow{3}{*}{$\begin{array}{l}\text { Human resources } \\
\text { (HR) }\end{array}$} & HR1 & $\begin{array}{l}\text { Professional departments related to information disclosure in } \\
\text { commercial banks are trained professionally and continuously }\end{array}$ & \multirow{3}{*}{ Proposed by authors } \\
\hline & HR2 & $\begin{array}{l}\text { The qualifications of the staff are fully met the requirements for } \\
\text { information preparation and publication }\end{array}$ & \\
\hline & HR3 & $\begin{array}{l}\text { The department involved with information disclosure is always } \\
\text { provided with sufficient human resources }\end{array}$ & \\
\hline \multirow{3}{*}{$\begin{array}{l}\text { Information } \\
\text { infrastructure } \\
\text { (IFS) }\end{array}$} & IFS1 & Database system is fully provided and in good condition & \multirow[b]{3}{*}{ Nguyen (2015) } \\
\hline & IFS2 & $\begin{array}{l}\text { Information about the bank's business activities are posted many } \\
\text { years in a row, continuous and still usable }\end{array}$ & \\
\hline & IFS3 & $\begin{array}{l}\text { Information technology infrastructure in all branches related } \\
\text { to commercial banks has been computerized to help publicize } \\
\text { information of commercial banks conveniently, quickly and } \\
\text { accurately. }\end{array}$ & \\
\hline \multirow{3}{*}{$\begin{array}{l}\text { Information } \\
\text { transparency } \\
\text { (TRA) }\end{array}$} & TRA1 & Information provided by banks is transparent and public & \multirow{3}{*}{ Proposed by authors } \\
\hline & TRA2 & I believe in banks' information transparency & \\
\hline & TRA3 & I am satisfied with banks' information transparency & \\
\hline
\end{tabular}

